\title{
CONTEMPORARY CHALLENGES IN MILITARY LOGISTICS SUPPORT
}

\author{
MSc Marta PAWELCZYK \\ Management and Command Faculty \\ War Studies University, Warsaw, Poland
}

\begin{abstract}
Nowadays, the most important factors that cause global market activity and have a big influence on logistics processes are: globalisation and rapid development of new technologies. In that environment, military logistics are operating incessantly alongside the supply of goods in times of war, peace and crisis. These logistics are focused on finding solutions for being more effective and economically profitable. Because of this, logisticians try to reduce costs and supply good faster, as well as trying to provide the right quality and service.. The current challenges in military logistics support have changed. The biggest challenge for all logistics processes is to provide services according to the $7 R$ formula (right time, right product, right quantity, right condition, right place, right customer, and right price). A logistics leader is important for every operational mission. Thanks to the leader making quick and smart decisions, successful termination of a mission is possible.

The article is based on the example of logistics support for the Polish contingent in Kosovo. In the light of the above, the aim of the article is to identify and estimate the situation of military logistics. The research problem is as follow: What are the biggest determinants of logistics processes in military area?
\end{abstract}

Key words: logistics, military logistics, challenges, supply chains, national contingent. 


\section{What is military logistics?}

The world is constantly changing. Ideas which seemed impossible a few years ago are real today. The developments of new technologies, knowledge, services etc. are providing new possibilities, but also bring new needs to satisfy. The same changes are faced by logistics in the military. Logistics comes from the ancient Greek logos which mean "ratio, word, calculation, reason, speech, and oration" (Wikipedia 2017).

Admiral Henry Eccles defined logistics as the bridge between military operations and a nation's economy (Paparone and Topic 2014). This combination is represented in a nation's resources, processes and systems that are used to generate materiel and personnel. According to the approved NATO definition, military logistics is the science of planning and carrying out the movement and maintenance of forces. Logistics includes interest in the following areas:

- design and development, acquisition, storage, transport, distribution, maintenance, evacuation and disposal of materiel;

- transport of personnel;

- acquisition, construction, maintenance, operation and disposition of facilities;

- acquisition of provision of services;

- medical and health service support (North Atlantic Treaty 2017).

The above mentioned areas of interest reflect the multidimensionality of military logistics. Generally, all these services and obligations are divided into three groups:

- production logistics;

- in-service logistics and

- consumer logistics (North Atlantic Treaty Organization 2017).

Production logistics is closely connected to the industrial domain. The core processes implemented in that sector includes: planning, organising and design, and procurement of equipment. All these tasks support standardisations which help people all around the world make the flow of goods faster, better and without mistakes. Moreover, it is concerned with reliability and maintainability analysis, interoperability, safety standards for equipment, quality assurance, acquiring spares, specifications and production processes, trials and testing, codification, 
documentation and configuration control. Every country is responsible for providing the equipment and maintaining military forces. Military cooperation between all these countries is coordinated by NATO in numerous spheres. The main duty of in - service logistics is filling the gap between production and consumer logistics. This is related to the core functions, which are: receiving, procuring, storing, distributing, and providing materials which are needed for providing the forces. It is also linked to ensuring the weapons system (checking if required equipment is available and suitable for use). Consumer logistics, also called operational logistics, relates to the supply and support functions of forces. It requires the collection of the initial product, storage, transport, maintenance, operation and disposal of materiel. As a consequence, consumer logistics covers stock control, provision and construction of facilities, movement and control. Furthermore, logistics in that aspect concern reliability and defect reporting, safety standards for storage, transport and handling and related training (North Atlantic Treaty Organization 2017).

Military logistics concerns all processes and systems involved in generating, transporting and redeploying or reallocating materiel and personnel. The military power of a specific country depends on the ability to accomplish the above stated functions. The more efficiently these logistics operations are, the more strategic and flexible a country is. Moreover, a specific nation has the potential to be granted a position of advantage. The above mentioned functions are the results of a level of war which can turn the tactical into strategic.

Inaddition, theirimplementation includesthejoint, interagency, intergovernmental and multinational domains. The foundation of military logistics is the production and procurement of military forces. This has a direct impact on the reaction that can also mobilise a country. Furthermore, it influences how long the specific country can withstand a conflict. Logistics support can improve the mission; however, it can also destroy it. All logistic processes must be prepared for every situation, especially when a conflict has arises that had not been previously planned.

Transportation is an extended process which includes the movement of personnel and materiel from the place of origin to a theatre of operations. To accomplish this function, it must provide the suitable resources at each level of war as it sets up in bases and lines of communications and secures them. The 
infrastructure of potential theatres of operation will be the base of action and present the test of strength to the logisticians as they try to establish supply and distribution networks. In order to acquire strategic flexibility beyond attack into enemy territory, a military claim extends the operational reach and endurance. Sustainment - considers all processes, tasks and systems connected with supplying, distributing, warehousing, and maintaining personnel or equipment. The main issues of militaries are effective and integrated sustainment organisations and leadership to deploy personnel and materiel, which have been gathered and moved to a theatre. Redeployment and reallocation are really close to the civilian industry's "reverse logistics," and take place on multiple levels. In military logistics, these aspects contain the military's ability to evacuate personnel or materiel. The aims of this function are for purposes of medical care, maintenance and reconstitution. The most important thing for soldiers who are wounded in combat is guaranteeing them proper medical care. Awareness of that can affect morale in the unit and also assuages fears on the home front. Redeployment and reallocation at national level are linked to termination of a conflict, or a shift of mission (North Atlantic Treaty Organization 2017).

The above described functions exist on each level of war (operational, tactical, and strategic). The most important aspects of logistics are to connect all processes to provide the right services in the operational theatre. The biggest challenge for all nations is to react to changing situations so that they can be more successful at specific missions. The more flexible a certain country is, the more effective it is. Logistics is of vital importance for any military operation. Without it, operations could not be carried out and sustained, especially in the case of out-of-area operations.

\section{The main logistics challenges in military area}

The best way to present the main challenges in the logistics field is to explain the 4D formula which includes: demand, distance, destination and duration (Major and Strickmant 2011). These determinants describe the conditions of every operation. Furthermore, these aspects define the planning and organising of a certain mission. The above mentioned parameters have to be adjusted to 
the different environments of operations and to frictions in the logistics support chains. Tensions may arise due to the variety of subjects functioning at local, national or international level (different government representatives, international partner organisations, contacting organisations, and EU institutions). Distances and destinations are aspects that can be simply estimated. These aspects are linked into logistical planning processes. However, these two points can also create some serious challenges: some placements are not readily available, do not have access to basic infrastructure or are in the middle of the operation theatre. Furthermore, transportation of soldiers, equipment and services over long distances is tough and expensive. The important question is demand and the duration of missions. They are established in the mandate of a mission. It is possible to extend the mandate depending on the situation. From a logistics point of view, it is a really difficult situation because all previously organised plans have to be adjusted to current requirements. A further difficult issue is demand. It is problematic to estimate all of the materials and equipment needed. Situations on a mission can be unpredictable, so the logistics team has to be prepared for sudden issues and instant reacting. The core logistical challenges for military operations are: the cost of logistics, transport and the outsourcing of logistics (Major and Strickmant 2011).

Transport, also called strategic and tactical lift, is essential for any mission. The strategic lift is a process which begins at the place of origin and finishes at a place close to the operational theatre. The tactical lift is the process which is provided close to the conflict zone, so that needs more protection and different requirements. This type of transport is related to small units of transportations. Strategic air lift is usually provided by transport aircraft. The remaining tactical sealift is provided by helicopters. Nowadays, it is important to ensure effective and adequate strategic and tactical lifts at short notice. In that context, it is difficult to assert proper transport capacities because of time and availability. Rapid reaction is the main challenge for the EU Battle group. In that concept, it is mentioned that it has to be in the region of operation within ten days after an official decision has been taken. When the crisis breaks out and when the EU decides to intervene, it cannot afford to waste time (Major and Strickmant 2011).

The most important aspect is sufficient air lift in order to operate over a distant and wide area of combat. Specialists are concerned about the cost of tactical and strategic transport. Sea lift is cheaper than air transport, but unfortunately 
takes more time. In order to reduce costs, the use of combined transportation is increasing. Air lift is the fastest and the most expensive way of transportation. The biggest advantage of this type of transportation is that helps with rapid deployment of units in a short amount of time. This aspect is helpful when it concerns emergency reactions, to offer the troops a quick place away from the place of origin at short notice. In the past, access to some places was that difficult that the only way of transportation was by air. The fundamental infrastructure was poor, which made trouble even for tactical aircraft. Most EU Members prefer support leasing and coordinating initiators, because the transportation process is expensive and rare. This idea is more realistic when considering the economic point of view (Major and Strickmant 2011).

Logistic processes depend on the availability of capabilities and on the cost of these operations. In civilian logistics, the biggest problem for all logistics departments is reducing expenses and making the processes more efficient. The same problem appears in military logistics. In 2004, the Council of the European Union launched the Athena mechanism to help EU members by funding military operations (Rada Europejska 2018). The main idea of the programme is the organisation and administrative cost of military operations, which are: fuel, accommodation and others connected to national contingents.

In all cases, these costs are:

HQ implementation and running costs, including travel, IT systems, administration, public information, locally hired staff, Force Headquarters (FHQ) deployment \& lodging;

for forces as a whole, infrastructure, medical services (in theatre), medical evacuation, identification, acquisition of information (satellite images);

reimbursements to/from NATO or other organisations (e.g. the UN) (Rada Europejska 2018).

Countries included in the programme must contribute according to their income (gross national income). Athena may also pre-finance other expenditure relating to an operation, particularly in the area of real-life support. All specific processes and rules of financing operations are defined by special regulations (Rada Europejska 2018). 
Nowadays, transport processes, support services and accommodation are making the operational cost high. As a result, countries try to minimise cost, by forwarding some of it to subcontractors. The increasing use of private subcontractors has become visible. EU member states are more willing to use private companies that provide outsourcing. This solution has a lot of economic advantages but also some disadvantages. It can reduce the total cost of operations and help to increase the quality of the process. The biggest disadvantage is that military operations rely on external partners who are focused on the business market. There can also be some difficulties with formal agreement between partners (government and private companies). Private sources can be more dangerous for military operations when considering the security of supply processes. In cases of crisis in Europe, outbound companies will meet increased cost levels because they're not disposing of their own capacities and have to stock up on the global market (Major and Strickmant 2011).

Logistics support guarantees the success of military operations. The most important factor for every operation is the team of people responsible for estimating all determinants. Military operations are often unpredictable, which means that the leader of the logistics team has to be able to react logically, responsibly and fast. A good logistic leader can indirectly contribute to the success of a military operation.

\section{National contingent in Kosovo}

According to the Cambridge Dictionary, a contingent is a group of people representing an organisation or country, or a part of a military force (Cambridge Dictionary 2017). It is a temporary military unit, created to provide military support in peacekeeping and stabilisation missions.

Every peacekeeping mission is based on logistics processes. At the end of the supply chain, there are subdivisions which are responsible for accomplishing all required tasks. The main duties of the Polish national contingent can be to:

- provide security and stability;

- prevent acts of violence and terrorism;

- enforce interruptions between conflicting parties; 
- fight resistance and terrorist and criminal groups;

- create, train, equip and diffuse armed forces and security forces;

- carry out border protection and border control;

- support development and justice and protection of government institutions;

- demonstrate strength and preparedness to combat threats;

- cut off the support and support for terrorist groups from the local population;

- carry out recognition and continuous monitoring of terrorist groups;

- strengthen protection by systematic patrolling of endangered areas and facilities;

- support state institutions and institutions and ensure proper functioning;

- reconstruct basic infrastructure;

- support civilians (Nowa Strategia 2014).

The military supply chains concern all processes needed to gather, deliver and provide services such as: transport, medical, communication, repairs, habitation etc. Logistics activity is focusing on providing support in order to fulfil combat readiness.

The main task of military supply chains is to provide an effective flow of products (medicine, food, ammunition etc.) to military units during times of peace or war. Logistics in the military area have to be prepared for various situations in order to achieve fluency in processes. Military logistics chains contain the activities shown in Figure 1.
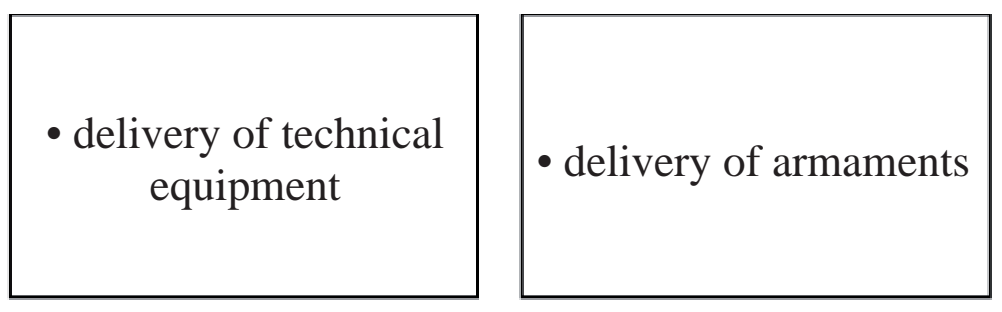

- delivery of metrical and technical material

Source: Author's own elaboration.

- provide logistics services (laundry, accommodation, right hygienic conditions etc.)

\section{Fig. 1. Core military logistics chain activities}


The main aim of the logistics department is to be responsible for providing the right goods for the occasion. There are also some requirements that logistics chains must fulfil. The fundamental role is for logistics chains to be compatible with strategy. All processes are supposed to be subordinated to the main vision of working. Apart from that, they should be functional in order to meet the conditions of information, provide an effective system which shows stock quantity, and allow the swift placing of orders for missing materials. Moreover, logistics in the military must be dynamic and flexible, because all supply chains are supposed to adapt to changing conditions on the battlefield. The logistics department should be aware of the rationality of using every element of supply chains and the correct exploitation of infrastructure (the right way to store weapons, food, and ammunition) (Szymański 2007). Supply chains at the battalion level are the most changing structures thanks to the different dynamics of the launched action. Figure 2 shows the core and functional capabilities of military logistics.

\section{CORE LOGISTICS CAPABILITIES}

\begin{tabular}{|c|c|}
\hline Core Capabilities & Functional Capabilities \\
\hline Supply & $\begin{array}{l}\text {-Manage Supplies and Equipment } \\
\text { - Inventory Management } \\
\text {-Manage Supplier Networks }\end{array}$ \\
\hline Maintenance Operations & $\begin{array}{l}\text {-Depot Maintenance Operations } \\
\text {-Field Maintenance Operations } \\
\text {-Manage Life Cycle Systems Readiness }\end{array}$ \\
\hline Deployment and Distribution & $\begin{array}{l}\text {-Move the Force } \\
\text {-Sustain the Force } \\
\text {-Operate the Joint Deployment and Distribution Enterprise }\end{array}$ \\
\hline Health Service Support & $\begin{array}{l}\text { - Casualty Management } \\
\text {-Patient Movement } \\
\text {-Medical Logistics } \\
\text {-Preventive Medicine and Health Surveillance } \\
\text {-Theater Medical Information }\end{array}$ \\
\hline Engineering & $\begin{array}{l}\text {-Combat Engineering } \\
\text {-General Engineering } \\
\text {-Geospatial Engineering }\end{array}$ \\
\hline Logistics Services & $\begin{array}{l}\text {-Food Service } \\
\text {-Water and Ice Service } \\
\text {-Base Camp Services } \\
\text {-Hygiene Services }\end{array}$ \\
\hline Operational Contract Support & $\begin{array}{l}\text {-Contract Support Integration } \\
\text {-Contract Management }\end{array}$ \\
\hline
\end{tabular}

Fig. 2. Core and functional logistics capabilities (Knight 2012) 
From a logistics point of view, the most important factor is to prepare a battalion to complete its duties abroad. Providing logistic services relate to the following aspects:

- estimating the amount and type of materials;

- providing all necessary equipment (cars etc.) for the current conditions at the mission area;

- replacing fluids, sealants, tyres, and exact verification of equipment;

- providing the right equipment (weapon, bulletproof vest, helmet etc.) for soldiers who are taking part in the mission;

- carrying out medical tests and protecting injections;

- packing all gathered equipment and staff to transport containers and preparing them for transport;

- preparing the right transportation and customs documents;

- planning and organising the movement;

- preparing financial assignments for all gathered goods (Szymański 2007).

It is a good idea to have a complete group of logisticians with people who are well prepared for their duties. These people will be responsible for the managing of materials, technical staff and warehousing. There is no representation of a perfect logistics team - all missions have different requirements and a different way of providing services. The most important thing is to notice these characteristics and provide the right services applicable to them.

People from the logistics unit have to provide services which will help a battalion function. Because of that, logistic officers have to help several different departments. For example: tank and cars, communications, armaments and electronics, connection and IT, sapper, chemical, feeding and many more.

Warehouse workers are needed for all the above mentioned services. The logistics team is also responsible for the reports system (Logistic reports and transport reports) sent to the supervisor. Supervisors can, thus, monitor the level of inventory, number of used articles and all the battalion's needs. Additionally, logisticians have to control transport and army movement. Damages and losses must be monitored and controlled by another person who is responsible for the mentioned process and guarantee the correct procedures if necessary Kosovo battalion units consist of: supervisor of the section, transportation officer, and 3 people responsible for planning, technical and material departments. 
Accomplishments of processes have to be coordinated on every level of management. To provide full coordination of these processes, one main person is needed. This person is supposed to be responsible for coordination and managing the logistics task.

The head of logistics should be subordinate to the Battalion Commander (or Chief of Staff) and:

- person responsible for transport and logistics registration system (planning and transport section);

- persons responsible for logistic services (max. 2 specialisations per person).

The best solution would be to create a technical and material section. Furthermore, the heads of these sections would be heads of departments at the same time. This model of logistics strategy is suitable for every level of command.

National contingent activities are based on fully securing all the logistical needs of the forces involved in performing missions in the mission area. In each military mission, the scope of the logistics services needs is different. This is dependent on the approved international agreements. However, in all military missions, the logistics of battle groups or battalions must keep records of property that should be credible and updated with the main records. Discrepancies between registration and real status must be clarified. Moreover, in the case of damage to property, investigative procedures are needed in accordance with the regulations in the Polish Army.

Battalion logistics in Kosovo was fully responsible for securing logistical needs. The supplying organ was the NSE stationed in Macedonia, which provided supplies in all classes except Class I (food for meal preparation).The supply of the battalion was as follows:

Class I

- dry rations - NSE;

- food for daily cooking and water;

- weekly delivery by DANISH CAMP SUPPLY (then segregation and delivery to the base);

- bread received daily from the French bakery. 
All other classes were also supplied by the NSE. The supply system was based on the monthly requirements that were submitted to the NSE. After the deployment of the battalion in Kosovo Mitrownica, the units were deployed in three different bases: the main, the company, and the platoon. The location of the battalion at three different bases made it difficult to secure appropriate social and living conditions. Subdivisions were based at NS-10 with tents and crucial equipment such as tables, stools, beds (Szymański 2007).

In that mission, the logistics department met some problems and found it necessary to provide different services. The main ones were:

- providing adequate electricity to the tents and connecting heating devices (lack of high power generators and the appropriate tooling and specialist);

- proper food storage (not enough refrigerated containers) in the initial phase;

- nutritional status was based on the field kitchen KPZ-100 but food was eaten under NS-10 tents. After a few months, a canteen was set up in a tent that was delivered;

- the need to provide and create the capacity to provide laundry, bathing and toilet services (problem with signing a contract with a local company for the provision of toilet services and connecting removable container baths) - no instrumentation for connection [pumps, PVC pipes, waste containers], ensuring the removal of impurities);

- maintenance and repair of vehicles;

- waste disposal (cooperation with local authorities).

The logistical section dealt with controlling and monitoring of the transportation process of troops in the area of responsibility. This task included sending information about planned convoys and other major trips to the leader. If the planned trip was outside of the battalion's liability zone, consent was required. To get that consent, it was mandatory to report the following information:

- exact date and time of departure from particular transport bases;

- route;

- the convoy commander;

- number of vehicles broken down by type;

- number of people involved in transport;

- codename and frequency of the convoy commander;

- satellite phone number. 
Depending on the destination of the convoy, the requirement was sent 24 to 48 hours before. After obtaining the transport permit and receiving the transport number, the person from the logistics section who was responsible for transport completed all necessary documents for the convoy commander (transport number, list of persons involved in the convoy and equipment, number of persons and escorted equipment, etc.) and conducted the instruction (Szymański 2007).

The role of logistics services in preparing a contingent to complete a military mission or rotation is huge and different for each mission. During the Kosovo mission, logistics had to complete full operations, as it was decided to withdraw the battalion to the country. Three bases in which the battalion was in service were abolished, and brought to the state from the battalion entrance.

In conclusion, the level of logistic operations could possibly be the highest all the time. Even if the battalion has a perfect strategic plan without proper support (accommodation, equipment, food, weapons), it cannot be accomplished. Every logistics mission requires a logistics leader who can quickly react in different situations. The more flexible a logistics team is, the more efficient certain operations are. It is essential to create a logistics team which includes specialists in different areas linked to logistics support. Unqualified people can make some mistakes, which can be dangerous for military missions.

\section{References}

Cambridge Dictionary, 2017. [online] Available from http://dictionary.cambridge.org/ dictionary/english/contingent [Accessed 15 Sept 2017].

Paparone Ch. R., Topic G. L. 2014. The "Clausewitz" of logistics: Henry E. Eccles. [online] Available from https://www.army.mil/article/117963/the_clausewitz_of_logistics_ henry_e_eccles [Accessed 20 May 2017].

Knight C. B. 2012. Sustainment Preparation of the Operational Environment Planning and Assessment Tool. [online] Available from http://www.alu.army.mil/alog/PDF/ NovDec2012/Nov_Dec_2012.pdf [Accessed 21 June 2017].

Major C., Strickmant E. 2011. You can't always get what you want - Logistical Challenges in EU Military Operations, Stiftung Wissenschaft und Politik, Berlin.

North Atlantic Treaty Organization 2017. [online] Available from http://www.nato.int/ cps/en/natohq/topics_61741.htm [Accessed 21 June 2017]. 
Nowa Strategia, 2014. Zakres zadaniowy polskich kontyngentów wojskowych w Iraku i Afganistanie. [online] Available from http://www.nowastrategia.org.pl/zakreszadaniowy-polskich-kontyngentow-wojskowych-iraku-afganistanie/ [Accessed 15 Sept 2017].

Rada Europejska, 2018. Athena - finansowanie wojskowych operacji bezpieczeństwa i obrony. [online] Available from http://www.consilium.europa.eu/pl/policies/athena/ [Accessed 5 Mar 2018].

Szymański M., 2007. Aspekty przygotowania, działalności oraz zaopatrywania polskich kontyngentów wojskowych, Zeszyty Naukowe. Logistyka i Transport / Międzynarodowa Wyższa Szkoła Logistyki i Transportu we Wrocławiu, Vol. 4, No. 1.

Wikipedia, 2017. Logistics. [online] Available from https://en.wikipedia.org/wiki/Logistics [Accessed 22 June 2017]. 